\title{
Studiu asupra percepției şi al modului de abordare parental privind pneumonia comunitară la preşcolarii din România
}

\author{
Alexandra Guțăă , Mihai Craiu² \\ ${ }^{1}$ Spitalul Clinic de Urgenţă „Sf. Pantelimon“, Bucureşti, România \\ ${ }^{2}$ Compartimentul Primiri Urgenţe din cadrul Institutului Naţional pentru Sănătatea Mamei şi \\ Copilului „Alessandrescu Rusescu“, Universitatea de Medicină şi Farmacie „Carol Davila“, \\ Bucureşti, România
}

\begin{abstract}
REZUMAT
Introducere. Pneumonia comunitară este foarte frecventă şi este responsabilă de $16 \%$ dintre decesele la copiii cu vârstă de pană la 5 ani. Scopul prezentului studiu a fost să identifice potenţiali factori modificabili/influenţabili în legătură cu percepţia parentală privind managementul pneumoniei la copil. Conturarea unor astfel de factori ar permite elaborarea unor strategii de scădere a morbidităţi asociate pneumoniei în România.

Materiale şi metode. A fost realizat un studiu transversal în perioada 25.08.2016 - 27.08.2016 ce a constat în distribuirea la nivelul platformelor de socializare a unui formular de tip Google Form pentru părinţii copiilor cu vârstă între 4 luni şi 5 ani. Chestionarul a cuprins 26 întrebări distribuite în 5 secţiuni. Colectarea datelor şi analiza statistică a fost realizată prin intermediul Microsoft Office Excel Worksheet.

Rezultate. Au răspuns 1.083 de părinţi. La întrebarea privind statusul vaccinal am primit următoarele răspunsuri: 973 de copii sunt vaccinaţi (89.8\%) conform Schemei Ministerului Sănătăţii şi 90 sunt vaccinaţi incomplet sau nevaccinaţi.

378 de copii au fost alimentaţi natural mai puţin de 4 luni sau niciodată. 32\% (352) au diversificat la o vârstă mai mică de 4 luni şi 19\% (201) după 6 luni.

46,91\% (508) din copii au avut infecţii acute de căi respiratorii şi 42,41\% (215) dintre aceştia au avut nevoie de internare. Pe primele două poziţii ale simptomelor care i-ar determina să se prezinte cu copilul la medic se află febra 47,83\% (518) şi tusea 19,58\% (212). 38,87\% (421) dintre respondenţi au administrat medicamente fără a cere sfatul unui medic, iar $61,3 \%$ (358) din respondenţi administrat analgezice şi antipiretice.

Pneumonia a fost recunoscută drept o boală gravă care poate determina uneori deces de către $69,07 \%(748)$ dintre respondenţi.

Discuţii. Deoarece în literatură există dovezi ale unei corelaţii a morbidităţii şi mortalităţii în pneumonia copilului mic cu statusul socio-economic şi cu cel educaţional familial, am dorit să explorăm şi alţi factori potenţial incriminabili, în această epocă de semnificative modificări de percepţie parentală şi de comportament social sau de comunicare.

Concluzii. Scăderea ratei de acoperire vaccinală în România (89\% la acest grup selectat de pacienţi cu acces la Social Media) a dus la coborârea sub pragul la care se menţine imunitatea de grup.

Părinţii din România care au răspuns la chestionar au obţinut un scor bun la recunoaşterea simptomelor şi aprecierea gravităţii pneumoniei. Numărul mare de respondenţi incluşi în studiu într-un timp scurt este un indicator al dorinţei părinţilor de a se informa. Această schimbare de comportament a noii generaţii de părinţi din ţara noastră ar putea genera alternative la strategiile educaţionale existente.

Elaborarea unor surse Social Media de informaţii medicale în limba romană precum şi îndrumarea părinţilor către acestea ar putea duce la îmbunătăţirea calităţii informaţiilor deţinute de părinţi.
\end{abstract}

Cuvinte cheie: pneumonie, copil, educaţie, Social Media

\section{INTRODUCERE}

Pneumonia comunitară (PC) este o infecție pulmonară cauzată de patogeni achiziţionați în afara mediului spitalicesc şi reprezintă cea mai frecventă cauză de deces prin infecții la copiii cu vârstă sub 5 ani. Este responsabilă de $16 \%$ dintre decesele la aceasta grupă de vârstă în 2015 (1,2,5). Deşi în intervalul 2000-2015 a scăzut la jumătate numărul deceselor prin pneumonie la copilul mic cifrele ră- 
mân extrem de înalte: 922.000 pe an, 2.500 pe zi şi 100 pe oră (5). Decesele apar mai ales în țările subdezvoltate sau în curs de dezvoltare, 6 din 10 decese apărând în doar 10 țări - Nigeria, Angola, Ciad, Etiopia, Republică Democrată Congo, China, India, Pakistan, Afganistan, Indonezia $(5,6)$.

La această grupă de vârstă PC prezintă cea mai mare rată de internare şi generează costuri medicale crescute $(3,4)$.

La nivel global doar 3/5 dintre copiii cu PC au parte de îngrijiri corespunzătoare. Se poate scădea rata de apariție prin intervenții eficiente şi uneori simple: igienă corespunzătoare, apă potabilă disponibilă, îmbunătățirea calității aerului în locuințe, alimentație exclusiv naturală în primele 6 luni şi vaccinare de rutină (inclusiv antirujeolică şi antipertussis) (5).

În viitorul apropiat ar trebui implementate o serie de măsuri pentru a reduce morbiditatea şi mortalitatea prin PC. Experţii UNICEF au identificat dintre aceste strategii: vaccinarea anti-pneumococică, dispozitive medicale de diagnostic şi tratament accesibile [pulsoximetre şi concentratoare de oxigen ieftine], medicamente cost-eficiente. O cură de Amoxicilină sub formă de comprimate dispensabile, având un cost sub 50 cenți, este considerată ca fiind cea mai cost-eficientă intervenție terapeutică actuală în PC (5).

\section{OBIECTIVE}

Principalul obiectiv îl constituie evaluarea nivelului de cunoştințe al părinților/tutorilor de copii preşcolari cu privire la infecțiile respiratorii şi a pneumoniei. Obiectivele secundare sunt reprezentate de identificarea principalelor motive ale alegerii unor comportamente potențial dăunătoare sănătăţii copiilor în ceea ce priveşte vaccinarea şi modul de alimentație al acestora.

\section{METODE}

A fost realizat un studiu transversal în perioada 25.08.2016 - 27.08.2016 ce a constat în distribuirea la nivelul platformelor de socializare a unui formular de tip Google Form (Anexa 1) pentru părinţii copiilor cu vârstă între 4 luni şi 5 ani. Chestionarul a cuprins 26 întrebări distribuite în 5 secţiuni, însumând un număr de 1.146 de respondenți din care au fost incluşi în studiu 1.083, după ce au fost excluşi 61 de părinţi ce au completat eronat şi alți 2 rezidenţi în străinătate şi care au urmat complet alte scheme vaccinale - vezi designul studiului în Anexa 2.
Respondenților li s-a explicat scopul studiului iar completarea formularului a reprezentat acordul acestora de a participa la studiu. Chestionarul respectă criteriile stricte GCP (Good Glinical Practice guidelines) din ştiințele bio-medicale şi nu a cuprins niciun câmp cu privire la nume, CNP sau alte date cu caracter personal. Astfel a fost păstrată confidenţialitatea respondenţilor pe tot parcursul studiului şi a interpretării datelor.

Nivelul de cunoştințe al respondenților a fost evaluat prin intermediul unei întrebări de tip răspuns deschis, pentru a influența cât mai puțin răspunsul şi a încerca să se elimine bias-ul. Toate răspunsurile au fost apoi centralizate fiind alcătuit în scor al cunoştințelor conform Tabelul 1.

TABELUL 1. Scorul de evaluare a cunoştințelor părinților români cu privire la simptomele pneumoniei

\begin{tabular}{|l|c|}
\hline Criteriu clinic & Puncte \\
\hline - Febră/frison & $1 \mathrm{p}$ \\
\hline - Tuse & $1 \mathrm{p}$ \\
\hline $\begin{array}{l}\text { - Modificări în respiraţie/dureri toracice (exluzând } \\
\text { durerile descrise ca fiind „în piept“) }\end{array}$ & $1 \mathrm{p}$ \\
\hline $\begin{array}{l}\text { - Simptome nespecifice: alterarea stării generale, } \\
\text { diminuarea ape tului, nelinişte, vomă }\end{array}$ & $1 \mathrm{p}$ \\
\hline
\end{tabular}

\section{REZULTATE}

Din punct de vedere demografic a fost analizat numărul de persoane din locuința în care copilul trăieşte, astfel încât dintre cei 1.083 de respondenţi în 94,74\% dintre cazuri (1026) copilul locuieşte împreună cu ambii părinți, 4,34\% (47) dintre cazuri el locuieşte împreună cu unul dintre părinți, iar în aproximativ 1\% (10) acesta locuieşte împreună cu bunicii sau cu alte persoane. A fost analizat statutul pe piața muncii al părinților/tutorilor: $44,88 \%$ (486) mame se află în concediu de creştere al copilului, $34,16 \%$ (370) sunt active pe piața muncii. În ceea ce priveşte statutul taților 94,74\% (1026) sunt activi, iar $1,48 \%$ (16) se află în concediu creştere copil. În ceea ce priveşte nivelul de educaţie a fost analizat câți părinți au drept ultima formă de învățământ absolvită facultate/master/doctorat, în această categorie fiind încadrați 71,74\% (777) dintre mame şi 54,48\% (590) dintre taţi.

A fost analizată integrarea copilului în colectivitate - vezi Fig. 1. Dintre copiii integrați în colectivitate, $2,79 \%$ (11) sunt în colectivitate cu mai puțin de 5 copii, în timp ce $37,56 \%$ (148) sunt într-un colectiv de peste 20 de copii. Respondenții au fost chestionați cu privire la activitățile extracuriculare întreprinse de copii, 75,07\% (813) nu practică activități extracuriculare şi 24,93\% (270) practică astfel de activități. 


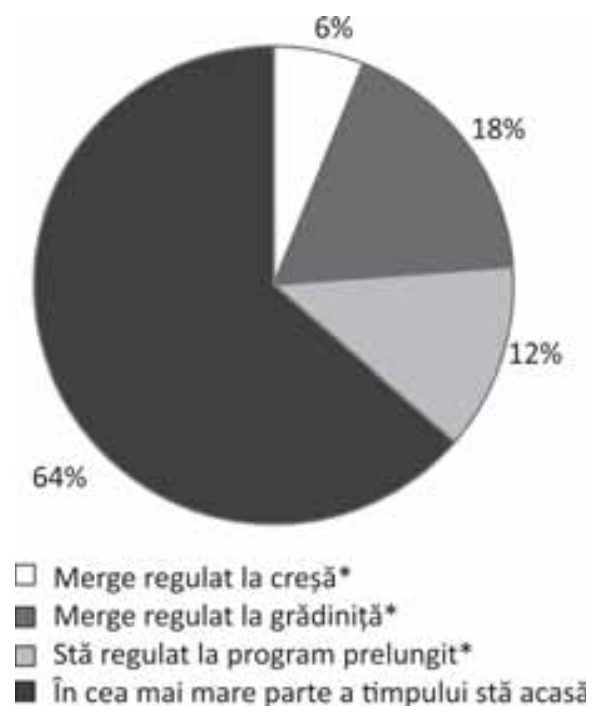

FIGURA 1. Integrarea copilului în colectivitate

A fost analizat statusul vaccinal al copiilor, 973 din aceştia fiind afirmativ vaccinați conform Schemei Ministerului Sănătătii (MS), 20 copii având şi vaccinuri opționale pe lângă schema Ministerului Sănătătii completă şi 90 din copii sunt vaccinați incomplet sau deloc. Părinții copiilor vaccinați incomplet sau nevaccinați au indicat următoarele motive ale acestei alegeri-vezi Tabelul 2.

TABELUL 2. Motivele nevaccinării în cazul copiilor nevaccinați sau vaccinați incomplet.

\begin{tabular}{|l|c|}
\hline Motivele nevaccinării & $\begin{array}{c}\text { Număr de } \\
\text { respondenți }\end{array}$ \\
\hline Nu 日/Nu răspund & 22 \\
\hline Neîncredere în eficienţă/siguranţă acestora & 21 \\
\hline Teama de reacţii adverse & 21 \\
\hline $\begin{array}{l}\text { Din cauza antecedentelor patologice ale } \\
\text { copilului }\end{array}$ & 11 \\
\hline $\begin{array}{l}\text { Am experimentat reacţii adverse post-vaccinale } \\
\text { în cazul copiilor mei }\end{array}$ & 8 \\
\hline Informare & 4 \\
\hline Lipsă vaccin & 3 \\
\hline
\end{tabular}

A fost analizat timpul de alimentație naturală exclusivă (în care copilul a primit doar lapte de
TABELUL 3. Motivele alegerii unei alimentații nesanogene

\begin{tabular}{|l|c|}
\hline Motive ale nealimentării suficiente & $\begin{array}{c}\text { Număr } \\
\text { respondenți }\end{array}$ \\
\hline $\mathrm{Nu}$ ⿴囗十 $/$ Nu răspund & 270 \\
\hline Lipsă lapte can ta v/calita v & 47 \\
\hline Condiţii medicale mamă/sarcina mul plă & 34 \\
\hline Copilul a refuzat sânul/Nu trăgea suficient & 15 \\
\hline Nu m-am informat/Nu am fost informată & 11 \\
\hline
\end{tabular}

mamă, fără niciun aliment, inclusiv apa/ceai/formulă): 705 de copii au fost alimentați natural 4-6 luni, 378 de copii au fost alimentați natural mai puțin de 4 luni sau niciodată. Au fost chestionate motivele alegerii unei alimentații nesanogene printr-o întrebare de tip deschis pentru a influența cât mai puțin răspunsul respondenților, acestea fiind ilustrate în Tabelul 3.

A fost analizată frecvența infecțiilor acute de căi respiratorii (IACR), 46,91\% (508) având IACR şi 53,09\% (575) neavând IACR. Dintre copii care au avut IACR 42,41\% (215) au necesitat internarea. Părinții au fost întrebați care este simptomul de alarmă care îi determină să se prezinte la medic, întrebarea fiind de tip răspuns deschis. În cadrul unor mai multe motive, a fost luat în calcul primul motiv indicat de părinţi, conform Tabelul 4.

TABELUL 4. Simptomul de alarmă care i-ar determina pe părinți să îşi aducă copilul la medic.

\begin{tabular}{|l|c|c|}
\hline $\begin{array}{l}\text { Simptomul de alarmă care îi } \\
\text { determină pe părinți să își aducă } \\
\text { copilul imediat la medic }\end{array}$ & $\begin{array}{c}\text { Număr } \\
\text { respondenți }\end{array}$ & $\begin{array}{c}\text { Procentaj de } \\
\text { răspunsuri }\end{array}$ \\
\hline Febră & 518 & $47,83 \%$ \\
\hline Tuse & 212 & $19,58 \%$ \\
\hline Respiraţie greoaie & 182 & $16,81 \%$ \\
\hline Nu đa/la orice simptom & 60 & $5,54 \%$ \\
\hline Nas înfundat & 52 & $4,80 \%$ \\
\hline Șuierat/Hârâit & 34 & $3,14 \%$ \\
\hline Modificarea stării generale & 20 & $1,85 \%$ \\
\hline Vărsături & 3 & $0,28 \%$ \\
\hline Roșu în gât & 1 & $0,09 \%$ \\
\hline Otalgie & 1 & $0,09 \%$ \\
\hline
\end{tabular}

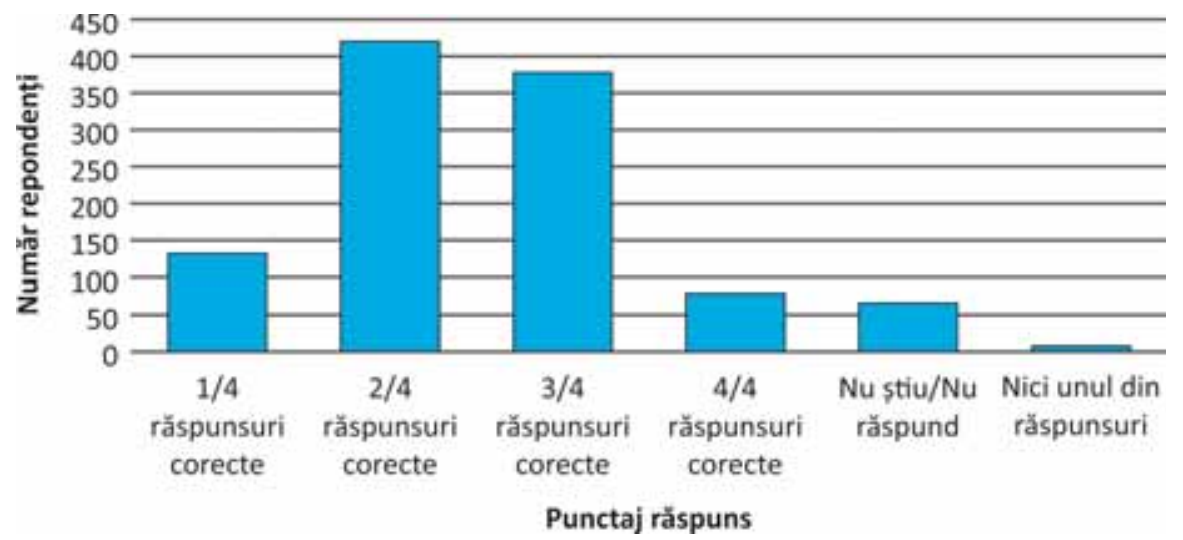

FIGURA 2. Evaluarea capacității de a recunoaşte simptomele pneumoniei 
Părinții au fost întrebați dacă ei consideră PC o boală gravă, care poate determina uneori deces. $69,07 \%$ (748) consideră pneumonia o boală gravă şi 30,93\% (335) nu consideră pneumonia o boală gravă, potențial letală. În ceea ce priveşte capacitatea respondenților de a recunoaşte simptomele pneumoniei acestea sunt prezentate în Fig. 2.

A fost chestionat modul în care părinții aleg să administreze medicamentele copiilor (reprezentat în Fig. 3). Din cadrul celor 584 de respondenți care au administrat medicamente fără a cere sfatul unui medic sau doar la sfatul farmacistului, 358 au dat analgezice şi antipiretice, 79 de medicamente care nu se regăsesc pe site-ul Agenției Naționale a Medicamentului, 48 au administrat medicamente antitusive şi expectorante, 24 antibiotice şi 75 alte tipuri de medicamente.

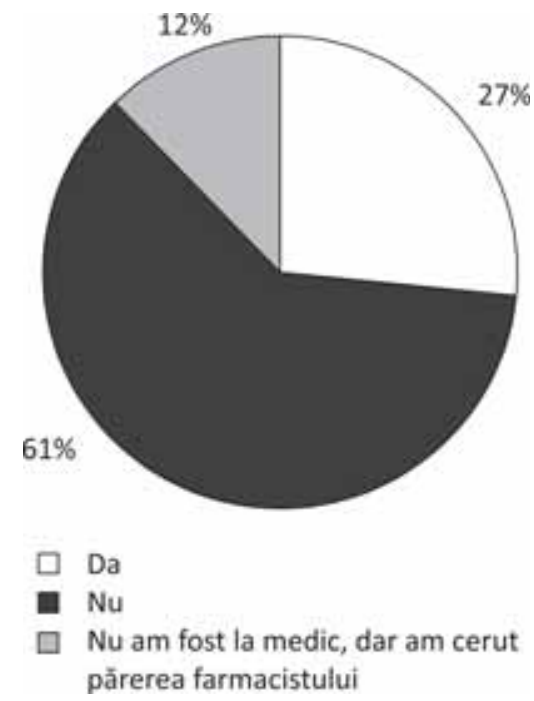

FIGURA 3. Ați administrat vreodată medicamente fără a cere statul medicului?

Prin intermediul analizei multivariate a fost analizată relația dintre modul de administrare al medicamentelor cu nivelul de educație al tatălui, obținându-se $\mathrm{R}^{2}=0,016, \mathrm{~F}=0,0003 \mathrm{cu}$ un coeficient de corelaţie de $-0,062$ şi $\mathrm{p}<0,001$.

\section{DISCUŢII}

Alegerea acestei grupe de vârstă pentru studiu, a fost bazată pe faptul că, vârstă mică, în special copiii sub 2 ani, necesită mai frecvent spitalizare. Înțelegerea modului în care părinții privesc infecțiile respiratorii şi implicit PC, poate ajuta la elaborarea unor strategii destinate acceptării mai uşoare a tratamentului şi a modului de evoluție a bolii.

Deoarece la cazurile de pneumonie a copilului având vârstă sub 5 ani există dovezi în literatură de corelație a morbidității şi mortalității cu statusul so- cio-economic şi educaţional familial am dorit să explorăm şi alți factori potențial incriminabili (7). Înțelegerea în perspectivă mai largă a factorilor de risc ce duc la apariția acestei patologii ar putea ameliora aceste statistici.

În literatură principalii factori de risc citați pentru a dezvolta pneumonie sunt astmul şi istoricul de infecții acute de căi aeriene inferioare. Alt factor menționat este educația parentală. Capacitatea de a citi a părinților sau a persoanelor din anturajul copilului ar putea influența rata de apariție a infecțiilor acute de căi aeriene inferioare $(8,9)$.

Cunoaşterea raționamentului pentru care părinții aleg practici cu impact negativ pe sănătate, respectiv vaccinarea incompletă sau nevaccinarea şi respectiv alimentația la sân neconformă cu indicațiile Societății Române de Pediatrie ar putea facilita înțelegerea trendului actual din România. Aceste aspecte ar putea duce la ameliorarea relaţiei medicpacient, având drept rezultat scăderea atât a morbidității şi mortalităţii cât şi a impactului negativ pe care pneumonia îl poate avea în ansamblu. Probabil ar putea avea un impact asupra calității vieții părintelui pacientului dar şi asupra costurilor şi a zilelor de concediu medical pe care părinții activi pe piață muncii sunt nevoiți să şi le ia în cazul apariției unei pneumonii a copilului lor (10).

Un alt factor de risc care poate fi explorat vine de la aşteptările parentale nerezonabile. Un studiu efectuat în clinica noastră arată că $67,82 \%$ din părinții copiilor prezentați cu febră la Compartimentul de Primiri Urgenţe aşteptau o rețetă de antibiotic, anterior diagnosticului (11). Acest demers ar putea să descifreze paradoxul asocierii între diagnosticul de pneumonie şi aşteptarea părintelui de tratament cu antibiotic, dat fiind faptul că în SUA doar 15\% dintre copii mici cu pneumonie spitalizați au o etiologie bacteriană sau virobacteriană (12).

Deoarece am efectuat această evaluare în cursul verii este posibil să fi ,ratat“ o parte dintre perceptiile parentale privind pneumoniile la copil, deoarece frecvența maximă a bolii este înregistrată iarna şi primăvara în țările cu un climat temperat (13). Un alt punct sensibil al prezentului studiu poate fi şi faptul că fost analizată prezența infecțiilor acute respiratorii, fără o precizare foarte riguroasă a topografiei acestora. În literatura de specialitate se analizează separat incidența infecțiilor acute de căi aeriene superioare/inferioare, iar analiza abordează atât copiii, cât şi persoanele din preajma acestora (14).

Vaccinarea anti-pneumococică, introdusă în august 2017, se aşteaptă să schimbe frecvența şi severitatea PC la copil în România, aşa cum s-a întâm- 
plat şi în cazul altor țări dezvoltate sau în curs de dezvoltare (15). Acest fapt ar putea să modifice perspectiva părinților copiilor imunizați anti-pneumococic fată de pneumonie şi ar putea să scadă aşteptările de prescripție de antibiotic şi tendința la automedicație. În prezentul studiu în cadrul regresiei multiple prin analiza corelației între modul de administrare al medicamentelor cu nivelul de educație parental s-a observat o tendinţă de corelaţie negativă, tații cu nivel de educație crescut tinzând să nu administreze medicamente fără sfatul unui medic, corelație sugerată şi de literatură (16). Este de subliniat faptul că, în cadrul administrării medicamentelor fără sfatul unui medic, pe al doilea loc, după medicamentele analgezice şi antipiretice, s-au clasat medicamente care nu se regăseau pe site-ul Agenției Naţionale a Medicamentului (ANMDM), cum ar fi medicamente de tip homeopat sau altele cu eficacitate şi siguranţă incertă.

Numărul mare de respondenți într-un timp scurt arată dorința părinților de a se informa, sursele din Social Media fiind foarte importante în opinia acestora. Foarte mulți caută informații în mediul on-line privind aspecte legate de sănătate. În cazul utilizatorului român din mediul urban deseori întrebarea este adresată unor interlocutori inadecvați şi puțin avizați, $31 \%$ apelând la sfaturile unor prieteni în Social Media, 32\% folosind blogurile şi 74\% forumurile generale (17). În cadrul Spitalului Virtual de Copii din totalul de 80.000 de urmăritori sunt peste 75.000 de părinți care apreciază pagina respectivă, putând sugera ponderea estimativă a celor cu viziuni anti-vaccinare şi anti-medicină alopată că fiind în jur de 5\% din totalul părinţilor activi în Social Media.

Probabilitatea asimilării acestui tip de mesaj educațional impune creşterea calității informațiilor postate pe canalele Social Media.

\section{CONCLUZII}

Respondenții au obţinut un scor bun la recunoaşterea simptomelor şi aprecierea gravităţii pneumoniei. Numărul mare, incluşi în studiu într-un timp scurt, evocă dorința părinților de a se informa. Elaborarea unor surse Social Media de informații medicale în limba romană şi îndrumarea părinților către acestea ar putea duce la îmbunătătirea calității informațiilor deținute şi facilitarea relației medicpacient.

Se consemnează în România o schimbare a modelului tradițional de îngrijire intra-familială, tații părând a-şi asuma o mai mare responsabilitate în îngrijirea copiilor, chiar dacă la ora actuală doar o mică proporție se află în concediu de creştere a copilului. Mai ales cei cu un nivel ridicat de studii tind să nu administreze medicamente fără a cere sfatul medicului.

O situație îmbucurătoare este şi aceea că, în cazul copiilor nevaccinați sau vaccinați incomplet, se remarcă o tendință mai mică de a administra medicamente fără sfat medical astfel încât aceştia se vor prezenta la medic în stadii precoce ale bolii.

Fiind un studiu de tip "single point survey" prezintă dezavantajele acestui model de studiu, reflectând comportamente parentale extrem de dinamice, posibil în schimbare. Această abordare ne plasează în incapacitatea de a stabili secvența temporală a evenimentelor. Există şi riscul unui grad de confuzie în perceperea întrebărilor chestionarului, de către părinți, deşi computer-literacy este într-o constantă ameliorare în ultimul deceniu. De aceea sunt imperios necesare elaborarea unor noi strategii de comunicare medic-pacient care să includă şi Social Media.

Mulțumiri lui Ştefan Nicolae pentru sprijinul acordat în prelucrarea şi interpretarea statistică a datelor. 


\section{ANEXA 1}

Anexa 1. Ches onarul distribuit ,, Lotului Internet"

* întrebări cu răspuns obligatoriu

Introducerea chestionarului: Bună ziua! Sunt studentă la facultatea de Medicină Generală în anul VI şi în prezent efectuez un studiu despre infecţiile respiratorii la copiii preşcolari (cu varste cuprinse între 4 luni şi 5 ani) studiu ce va fi folosit la realizarea lucrării mele de licenta. Datele pe care le completaţi în prezentul formular vor fi u lizate cu scopul strict de a fi interpretate sta s c, garantez deplina confidenţialitate a datelor pe care le completaţi. Completarea dvs. a prezentului formular cons tuie accordul dvs. de a par cipa la acest studiu. Vă mulţumesc!

\section{Secțiunea $1 / 6$}

Câți copii aveți?*

- 1

- 2

- 3

- 4

- Al el (specificaţi)

Copilul dvs./unul dintre copii are vârsta cuprinsă între 4 luni şi 5 ani?*

- Da

- Nu

Secțiunea 2/6 $\quad$ Lumea copilului - să ne cunoaştem! Pentru următoarele întrebări va rog să răspundeţi cu gândul la micuţul dvs. preşcolar, bifând doar câmpurile pentru cel mic între 4 luni şi 5 ani

Micuțul preşcolar (4 luni - 5 ani) locuieşte în prezent împreună cu:*

- Ambii părinţi

- Unul dintre părinţi

- Bunicii

- Al el (specificaţi)

Numărul persoanelor care locuiesc împreună cu copilul în aceeaşi casă:*

- 1-2 persoane

- 3-5 persoane

- Mai mult de 5 persoane

Ce afirmații i se potrivesc cel mai bine micuțului dvs. (regulat = mai mult de 3 zile/săptămână)*

- Merge regulat la creşă

- Merge regulat la grădiniţă

- Rămâne regulat la program prelungit

- Niciuna din cele de mai sus, în cea mai mare parte a mpului stă acasă

Pentru copiii care îşi petrec cea mai mare parte din timp la creşa/grădiniță/program prelungit. Câți copii se află în grupă/clasă cu copilul dvs.?

- Mai puţin de 5 copii

- 5-10 de copii

- 11-20 de copii

- Peste 20 de copii

Copilul dvs. practică diverse activități extracuriculare precum desen, sport, dans etc.?*

- Da

- Nu

Dacă da, câți colegi se află în clasă/grupă/colectiv cu acesta?

- Mai puţin de 5 copii

- 5-10 de copii

- 11-20 de copii

- Peste 20 de copii

\begin{tabular}{|l|l|}
\hline Secțiunea 3/6 & Despre copil \\
\hline
\end{tabular}

În prezent, copilul dvs. este vaccinat?*

- Da, conform schemei Ministerului Sănătăţii

- Al el (specificaţi)

Dacă nu, ce anume v-a determinat să nu îl vaccinați?

- Întrebare cu răspuns deschis

Despre alimentația exclusiv la sân, ce afirmații vi se potrivesc?*

- Da, I-am alimentat exclusiv la sân mai puţin de 1 lună

- Da, I-am alimentat exclusiv la sân până la 2 luni

- Da, I-am alimentat exclusiv la sân până la 3 luni

- Da, l-am alimentat exclusiv la sân până la 4 luni

- Da, l-am alimentat exclusiv la sân până la 5 luni

- Da, l-am alimentat exclusiv la sân până la 6 luni

- Da, l-am alimentat exclusiv la sân peste 6 luni

- Nu, nu I-am alăptat niciodată 
Dacă micuțul nu a fost alăptat, care au fost principalele motive pentru care ați făcut această alegere?

- Întrebare cu răspuns deschis

Copilul dvs. a fost născut prematur?*

- Da

- $\mathrm{Nu}$

La ce vârstă ați început diversificarea?*

- 2-3 luni

- 4 luni

- 5 luni

- 6 luni

- Peste 6 luni

Secțiunea 4/6 $\quad$ Părerea mamei despre boli

A suferit vreodată micuțul preşcolar de infecții acute de cai aeriene/boli pulmonare?*

- Da

- $\mathrm{Nu}$

Dacă da, a fost necesară internarea?

- Da

- $\mathrm{Nu}$

În cadrul unei infecții respiratorii care considerați ca este simptomul care v-ar determina să vă prezentați imediat la medic?*

- Întrebare cu răspuns deschis

Care considerați că sunt simptomele pneumoniei? (maxim 5)*

- Întrebare cu răspuns deschis

Considerați pneumonia o boală gravă care poate determina frecvent deces? *

- Da

- $\mathrm{Nu}$

Ați administrat vreodată copilului medicamente fără a cere sfatul unui medic?*

- Da

- Nu

- Nu am fost la medic, dar am cerut părerea farmacistului

Dacă da, ce anume?

- Întrebare cu răspuns deschis

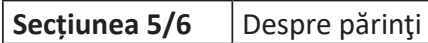

Ultima formă de învățământ absolvită de către mamă?*

- Şcoala primară 1-4 clase

- Şcoala gimnazială 5-8 clase

- Ciclul inferior al liceului 9-10 clase

- Ciclul superior al liceului 11-12 clase

- Facultate

- Master/doctorat

Ultima formă de învățământ absolvită de către tată?*

- Şcoala primară 1-4 clase

- Şcoala gimnazială 5-8 clase

- Ciclul inferior al liceului 9-10 clase

- Ciclul superior al liceului 11-12 clase

- Facultate

- Master/doctorat

Mama lucrează în prezent?*

- Da

- Nu

- Este în concediul de îngrijire al copilului

Tatăl lucrează în prezent?*

- Da

- Nu

- Este în concediul de îngrijire al copilului

Venitul pe membru de familie este de (adunați toate veniturile din gospodărie şi împărțiți la numărul de persoane care locuiesc acolo)*

- Sub 500 ron

- 500 - 1.500 ron

- Peste 1.500 ron

\begin{tabular}{|l|l|l|l}
\hline Secțiunea $6 / 6$ & Vă mulţumesc! \\
\hline
\end{tabular} 
ANEXA 2. Modul de formare a participanților din cadrul „Lot internet“

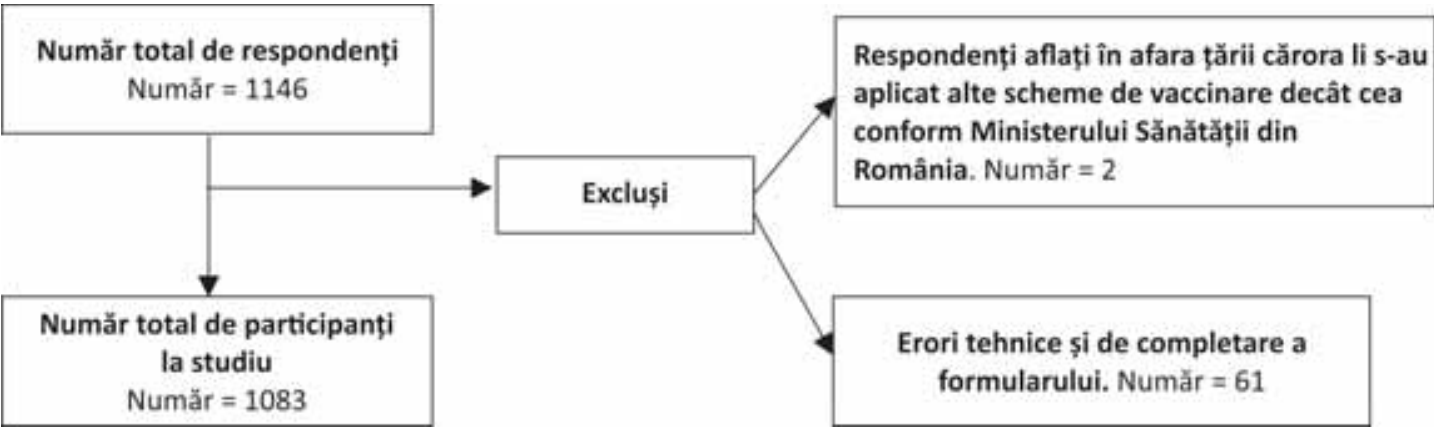

